Tér és Társadalom 18. évf. 2004/3. 91-110. p.

Tér és Társadalom

XVIII. évf. 2004 3: 91-110

\title{
KITEKINTÖ
}

\section{AZ AMERIKAI TRANSZNACIONÁLIS VÁLLALATOK TÉRSZERVEZÖDÉSE AZ 1990-ES ÉVEKBEN}

\author{
(The Geographic Distribution of U.S. Transnational \\ Corporations in the 1990s)
}

CSIKI ANITA

Kulcsszavak:

térszervezôdés transznacionális vállalat leányvállalat nemzetköziesedés vagyon

A tanulmány az amerikai vállalatok térszervezödését vizsgálja 1990 és 2000 között a nem banki amerikai transznacionális vállalatok tỏbbségi amerikai tulajdonban lévô külföldi leányvállalatainak megoszlásán keresztül. A kutatás az Amerikai Gazdaságelemzö Hivatal (Bureau of Economic AnalisyS [BEA]) Interneten is elérhetö adatbázisára épült'.

Az elemzés arra keresi a választ, hogy a 20. század utolsó évtizedében az amerikai vállalatok milyen világgazdasági pozícióval rendelkeztek, miként alakult e vállalatok nemzetköziesedettsége, hogyan módosult a vállalatok térszervezôdése, valamint hogy az ágazati folyamatokat tekintve milyen változások következtek be, és az egyes iparágak lokalizációja hogyan alakult.

A tanulmány az amerikai transznacionális vállalatok nemzetközi jelentöségének bemutatásával indít, ezt követi a vállalati tevékenység általános regionális elemzése, majd az egyes iparágak teruleti folyamatainak ismertetése, végezetül pedig sor kerül az amerikai vállalatok kelet-európai és magyarországi tevékenységének rövid felvázolására is.

\section{Az amerikai vállalatok nemzetközi pozíciója}

A hatvanas-hetvenes években a nemzetközi terjeszkedésben az amerikai vállalatok még egyértelmüen élen jártak, majd az európai és a japán vállalatok lettek egyre sikeresebbek. Számos amerikai vállalat versenyképessége csökkent akkoriban, mígnem a kilencvenes évek folyamán aztán ismét intenzívebbé vált az amerikai társaságok külföldi befektetői tevékenysége. Simai (2000) szerint ebben azon tényezők javulása játszott szerepet, amelyek a nyolcvanas években gyengítették az amerikai vállalatok globális pozícióját: jelentỏs technológiai fejlödés ment végbe mind az ipar (különösen az elektronikában és a biotechnológiában), mind a szolgáltatások terén; növekedett a vállalatok rugalmassága, racionalizálódott a vállalati hierarchia ("reengineering").

A transznacionális vállalatok nemzetközi jelentöségének megítélésében segítségünkre lehet az amerikai Fortune magazin által publikált, a világ 500 legnagyobb vállalatára vonatkozó jelentés. E szerint 2000-ben a világ 500 legnagyobb társasága 
közül 185-nek volt a headquartere az Egyesült Államokban, és ez a 185 vállalat a Global 500 profitjának megközelítőleg felét termelte meg (Global 5002001 ).

Az amerikai vállalatok világgazdasági szerepének értékelésére felhasználható még az ENSZ által a World Investment Reportban (WIR) közzétett 100 legnagyobb $^{2}$ nem pénzügyi vállalat listája is, amely tájékoztatást nyújt a külföldi és az összesített vagyon, a külföldi és az összesített értékesítés, a külföldi és az összesített foglalkoztatottság, valamint az ezekből a mutatókból számított, a nemzetköziesedés szintjét mérö index $\left(\mathrm{TNI}^{3}\right)$ alakulásáról. E szerint 2000-ben a 100 legnagyobb transznacionális vállalat közül 23-nak volt a föhadiszállása az Egyesült Államokban, ez a 23 vállalat rendelkezett a legnagyobb 100 vállalat összesített vagyonának harmadával, miközben a foglalkoztatottak $31 \%$-a is az ő alkalmazásukban állt, és az összesített értékesítés 33\%-át is ezen vállalatok bonyolították le (World Investment... 2002).

Igaz ugyan, hogy 1994 és 2000 között a 100 legnagyobb vállalat közé bekerült amerikai vállalatok száma 32-röl 24-re esett vissza, de mivel ugyanezen időszak alatt a foglalkoztatottak számából való részesedés csak 4\%-kal, a vagyonból való részesedés pedig csupán 3\%-kal mérséklődött, az Egyesült Államok vállalatainak világszintü jelentősége nem csökkent jelentös mértékben. És míg a fent említett mutatók az amerikai vállalatok visszaszorulására utalnak, addig az értékesítés terén tovább erősödött e vállalatok világpiaci jelentősége. Ezen túlmenően a TNI alakulása is azt mutatja, hogy az amerikai cégek nemzetközi jelenlétüket tovább fokozták (World Investment... 2002).

\section{A leányvállalatok térszervezödése}

Mivel különbség lehet a leányvállalatok térszerveződését illetően annak tekintetében, hogy az egyes térségeknek és államoknak az amerikai vállalati beruházásokból való részesedését a leányvállalatok száma (1. táblázat), vagy a leányvállalatok vagyona (2. táblázat) alapján vizsgáljuk, ezért mind a regionális, mind az ágazati folyamatok elemzésénél érdemes mindkét mutatót alapul venni.

Az Amerikai Gazdaságelemző Hivatal (BEA) 2000-ben már 2373 amerikai transznacionális vállalatot tartott nyilván, ezen vállalatok világszerte 23108 leányvállalattal rendelkeztek, melyek több mint $90 \%$-át a 4041598 millió dolláros vagyonnal rendelkezỏ többségi amerikai tulajdonban lévő leányvállalatok tették ki.

1990 és 2000 között a leányvállalatok száma évi átlagban 3,3\%-kal, vagyona 14\%-kal bővült, valamennyi régióban növekedés volt mérhető. Átlag feletti növekedés regionális szinten - mindkét mutató szerint - csak Ázsiában és LatinAmerikában volt. Európában a leányvállalatok számának évi átlagos növekedési rátája megfelelt a világátlagnak, de a vagyon e térségben is átlag felett növekedett. Az európai bővüléshez természetesen hozzájárult Kelet-Európának ${ }^{4}$, mint új beruházási célterületnek a megjelenése. Kanada, Afrika és a Közel-Kelet esetében azonban a bővülés mind a leányvállalatok számát, mind pedig azok vagyonát tekintve elmaradt a világátlagtól. 
Csiki Anita : Az amerikai transznacionális vállalatok térszerveződése az 1990-es években.

Tér és Társadalom 18. évf. 2004/3. 91-110. p.

TÉT XVIII. évf. 2004 匹 3

Kitekintö

93

$\mathrm{Az}$ amerikai cégek külföldi leányvállalatainak többsége még ma is a fejlett országokban koncentrálódik. 2000-ben az OECD államaiban lokalizálódott a leányvállalatok háromnegyede, igaz ez már némileg elmaradt az 1990-es értéktől, ugyanezen államoknak a vagyonból való részesedése pedig végig $85 \%$ körül alakult. Csak az Egyesült Államok melletti legerösebb államokat ${ }^{5}$ alapul véve elmondható, hogy a leányvállatok $40 \%$-a, a külföldi vagyonnak pedig fele müködött a világ vezető gazdaságaiban. Az említett két mutató alakulása azt sugallja, hogy a piac, az áruk és szolgáltatások értékesítésének lehetősége továbbra is nagyobb jelentőséggel bír a nemzetközi beruházási döntések során, mint az olcsó munkaerőforrás, illetve az egyéb eröforrások.

A külföldi leányvállalatok regionális megoszlását tekintve továbbra is Európa volt a legfontosabb beruházási területe az amerikai vállalatoknak, itt múködött a leányvállalatoknak több mint fele, és az amerikai transznacionális társaságok külföldi vagyonának $60 \%$-a is itt lokalizálódott. A kontinensen az amerikai befektetések túlnyomó része még mindig az Európai Unióra (EU) koncentrálódott, de a vizsgált időszak alatt a rendszerváltó kelet-európai régió szerepe is felértékelődött. Mivel az említett két országcsoport befektetési szempontból sem tekinthető homogénnek, így természetesen a vállalatok területi megoszlása is egyenlötlenséget mutat. Az Európai Unióba telepített leányvállalatok negyede létesült az Egyesült Királyságban, további harmada Németországban, Hollandiában és Franciaországban müködött. Ugyanez a vagyon esetében a következőképpen alakult: az uniós leányvállalatok vagyonának $45 \%$-át a brit leányvállalatok, további ötödét a holland és a német egységek vagyona tette ki. A vizsgált időszakban az EU-n belül számottevöen csak Írország szerepe értékelődött fel, ahol az új egységeket előbb az elektronikai cégek jelentették, de később jelentős beruházásokat hajtottak végre a gyógyszergyárak is. A koncentráció foka Kelet-Európában még az uniós szintnél is magasabb volt, a térségben létesítet leányvállalatok 60\%-a még 2000-ben is csak három államban (Lengyelországban, Csehországban és Magyarországon) lokalizálódott, s ezen államok a kelet-európai leányvállalatok vagyonának felével rendelkeztek.

Ázsia ${ }^{6}$ pozíciója a kilencvenes évek folyamán tovább erösödött. 2000-ben már a leányvállalatok ötöde müködött a térségben, melyek negyedét az újonnan iparosodott délkelet-ázsiai államokban (,NIC-országok”) létesített egységek tették ki, további 15\%-uk Japánban termelt, de fokozódott a többi feltörekvő délkelet-ázsiai állam, India és természetesen Kína jelentősége is. A legfeltủnőbb változás éppen ez utóbbinak a felértékelödése volt, ami részben a kínai reformmal, részben az ország világszinten is kiemelkedő gazdasági fejlödésével függ össze.

Ázsia a vagyont alapul véve az amerikai vállalatok második legfontosabb befektetési területe. A régió leányvállalatainak részesedése az összesített vagyonból a kilencvenes évek közepén már meghaladta a $18 \%$-ot, az évtized második felének végére - elsősorban az ázsiai pénzügyi válság következményeinek hatására - azonban 15\%-ra mérséklődött. Az ázsiai leányvállalatok vagyonának regionális megoszlását viszonylag nagy területi koncentráció jellemzi: 2000-ben a leányvállalatok vagyonának több mint harmada koncentrálódott a NIC országokban, de jelentős részesedéssel bírtak a japán egységek is. 
Csiki Anita : Az amerikai transznacionális vállalatok térszerveződése az 1990-es években.

Tér és Társadalom 18. évf. 2004/3. 91-110. p.

$94 \quad$ Kitekintö

TÉT XVIII. évf. 2004 a 3

\section{TÁBLÁZAT}

A leányvállalatok regionális megoszlása 1990 és 2000 között (\%-ban)

(The Geographic Distribution of Affiliates between 1990 and 2000)

\begin{tabular}{|c|c|c|c|c|c|c|c|c|c|c|c|}
\hline & 1990 & 1991 & 1992 & 1993 & 1994 & 1995 & 1996 & 1997 & 1998 & 1999 & 2000 \\
\hline Világ & 100 & 100 & 100 & 100 & 100 & 100 & 100 & 100 & 100 & 100 & 100 \\
\hline Kanada & 11,7 & 11,5 & 11,3 & 11,1 & 10,2 & 10,0 & 9,8 & 9,5 & 8,8 & 8,8 & 8,8 \\
\hline Európa & 51,0 & 51,2 & 51,3 & 51,9 & 51,2 & 51,2 & 51,2 & 51,3 & 51,1 & 51,1 & 51,2 \\
\hline Belgium & 3,3 & 3,3 & 3,2 & 3,2 & 3,0 & 3,1 & 3,0 & 3,0 & 2,9 & 2,5 & 2,5 \\
\hline Norvégia & 0,8 & 0,8 & 0,8 & 0,8 & 0,8 & 0,8 & 0,8 & 0,8 & 0,8 & 0,8 & 0,8 \\
\hline Franciaország & 6,1 & 6,2 & 6,2 & 6,3 & 6,0 & 6,0 & 6,0 & 6,0 & 5.8 & 5,6 & 5,6 \\
\hline Németország & 6,6 & 6,6 & 6,7 & 6,8 & 6,6 & 6,5 & 6,5 & 6,4 & 6,5 & 6,4 & 6,3 \\
\hline Írország & 1,6 & 1,6 & 1,6 & 1,6 & 1,5 & 1,6 & 1,6 & 1,6 & 1,7 & 1,9 & 1,9 \\
\hline Olaszország & 3,9 & 3,8 & 3,8 & 3,8 & 3,6 & 3,6 & 3,5 & 3,5 & 3,5 & 3,3 & 3,2 \\
\hline Hollandia & $5, I$ & 5,1 & 5,1 & 5,2 & 5,0 & 5,0 & 5,1 & 5,2 & 5,2 & 5,3 & 5,4 \\
\hline Egyesủlt Királyság & 12,7 & 12,8 & 12,6 & 12,5 & 12,0 & 11,9 & 11,8 & 11,7 & 11,4 & $\mathrm{I} 2,0$ & $12, I$ \\
\hline Európai Unió (15) & 46,8 & 47,0 & 3,0 & 47,1 & 45,6 & 45,6 & 0,0 & 0,0 & 44,8 & 44,6 & 44,9 \\
\hline Kelet-Európa & 0,0 & 0,1 & 0,3 & 0,6 & 1,6 & 1,7 & 1,8 & 2,0 & 2,3 & 2,8 & 2,7 \\
\hline $\begin{array}{l}\text { Lengyelország, Cseh- } \\
\text { ország és Magyarország }\end{array}$ & 0,0 & 0,1 & 0,2 & 0,4 & 1,1 & 1,1 & 1,2 & 1,3 & 1,4 & 1,7 & 1,6 \\
\hline Latin-Amerika & 15,5 & 15,4 & 15,4 & 15,1 & 15,0 & 15,0 & 15,1 & 15,3 & I5,7 & 16,1 & 16,3 \\
\hline Dél-Amerika & 6,5 & 6,5 & 6,4 & 6,4 & 6,3 & 6,4 & 6,4 & 6,6 & 7,1 & 7,5 & 7,5 \\
\hline Brazilia & 2,5 & 2,5 & 2,4 & 2,3 & 1,9 & 1,9 & 1,9 & 2,0 & 2,2 & 2,5 & 2.6 \\
\hline Közép-Amerika & 4,4 & 4.4 & 4,4 & 4,4 & 5,1 & 5,0 & 5,0 & 5,0 & 4,9 & 4,9 & 5,0 \\
\hline Mexikó & 2,7 & 2,7 & 2,8 & 2,8 & 3,5 & 3,5 & 3,6 & 3,5 & 3,5 & 3,8 & 3,8 \\
\hline Karib-szigetek & 4,6 & 4,5 & 4,5 & 4,3 & 3,6 & 3,6 & 3,6 & 3,7 & 3,7 & 3,7 & 3,8 \\
\hline Bahama-szigetek & 0,4 & 0,4 & 0,4 & 0,3 & 0,2 & 0,2 & 0,2 & 0,2 & 0,2 & 0,2 & 0,2 \\
\hline Bermuda-szigetek & 1,8 & 1,8 & 1,8 & 1,7 & 1,4 & 1,5 & 1,5 & 1,5 & 1,5 & 1,3 & 1,4 \\
\hline Afrika & 2,6 & 2,6 & 2,5 & 2,4 & 2,2 & 2,3 & 2,3 & 2,3 & 2,4 & 2,3 & 2,3 \\
\hline Egyiptom & 0,4 & $\overline{0,4}$ & 0,4 & 0,3 & 0,3 & 0,3 & 0,3 & 0,3 & 0,3 & 0.3 & 0,2 \\
\hline Nigéria & 0,2 & 0,2 & 0,2 & 0,2 & 0,2 & 0,2 & 0,2 & 0,2 & 0,2 & 0,2 & 0,2 \\
\hline Dél-Afrikai Köztársaság & 0,6 & 0,6 & 0,6 & 0,6 & 0,6 & 0,6 & 0,7 & 0,7 & 0,7 & 0,8 & 0,9 \\
\hline Közel-Kelet & 1,2 & 1,3 & 1,3 & 1,2 & 1,2 & 1,1 & 1,1 & 1,1 & 1.1 & 1,0 & 1,1 \\
\hline Izrael & 0,3 & 0,3 & 0,3 & 0,3 & 0,3 & 0,3 & 0,3 & 0,3 & 0,3 & 0,3 & 0,4 \\
\hline Szaúd-Arábia & 0,3 & 0,3 & 0,3 & 0,3 & 0,2 & 0,3 & 0,3 & 0,2 & 0,2 & 0,2 & 0,2 \\
\hline Arab Emírségek & 0,3 & 0,3 & 0,3 & 0,3 & 0,3 & 0,3 & 0,3 & 0,2 & 0,2 & 0,3 & 0,3 \\
\hline Ázsia, Ausztrália, Oceánia & 17,1 & 17,2 & 17,4 & 17,5 & 19,8 & 20,0 & 20,0 & 20,0 & 20,5 & 20,3 & 20,3 \\
\hline Ausztrália & 4,1 & 4,1 & 4,1 & 4,1 & 4,0 & 4,0 & 4,0 & 3,9 & 3,9 & 3,7 & 3,6 \\
\hline Kína & 0,3 & 0,3 & 0,3 & 0,4 & 0,9 & 1,0 & 1,1 & 1,3 & 1,6 & 2,2 & $2, I$ \\
\hline Hongkong & 2,3 & 2,3 & 2,3 & 2,3 & 2,7 & 2,7 & 2,7 & 2,6 & 2,5 & 2,4 & 2,3 \\
\hline India & 0,1 & 0,1 & 0,1 & 0,1 & 0,2 & 0,3 & 0,3 & 0,4 & 0,5 & 0,7 & 0.7 \\
\hline Indonézia & 0,7 & 0,7 & 0,8 & 0,7 & 0,8 & 0,8 & 0,8 & 0,7 & 0,8 & 0,7 & 0.6 \\
\hline Japán & 3,1 & 3,2 & 3,2 & 3,2 & 3,4 & 3,4 & 3,4 & 3,3 & 3,2 & 3,2 & 3.2 \\
\hline Dél-Korea & 0.6 & 0,6 & 0,6 & 0,6 & 0,8 & 0.8 & 0,8 & 0,8 & 0,9 & 0,9 & 0,9 \\
\hline Malajzia & 0,7 & 0,7 & 0,7 & 0,7 & 0,9 & 0,9 & 0,9 & 0,9 & 1,0 & 0,9 & 0,8 \\
\hline Fülöp-szigetek & 0,6 & 0,6 & 0,6 & 0,6 & 0,6 & 0,6 & 0,6 & 0,6 & 0,6 & 0,7 & 0,7 \\
\hline Szingapúr & 1,8 & 1,9 & 1,9 & 2,0 & 2,2 & 2,2 & 2,2 & 2,2 & 2,2 & 2,1 & 2,1 \\
\hline Tajvan & 0,9 & 0,9 & 0,9 & 1,0 & 1,1 & 1,1 & 1,0 & 1,0 & 1,0 & 1,0 & 1,0 \\
\hline Thaiföld & 0,6 & 0,6 & 0,6 & 0,6 & 0,8 & 0,8 & 0,8 & 0,8 & 0,8 & 0,9 & 0,9 \\
\hline$\overline{\mathrm{OECD}}$ & 78,8 & 79,1 & 78,9 & 79,2 & 78,6 & 78,3 & 77,9 & 77,2 & 75,9 & 74,9 & 75,2 \\
\hline "G7" tagok & 44,0 & 43,7 & 43,6 & 41,9 & 41,5 & 40,9 & 40,4 & 39,2 & 39,2 & 39,1 & 39,1 \\
\hline
\end{tabular}

Forrás: Bureau of Economic Analisys (BEA) alapján saját számítás. 
Csiki Anita : Az amerikai transznacionális vállalatok térszerveződése az 1990-es években. Tér és Társadalom 18. évf. 2004/3. 91-110. p.

\section{TÁBLÁZAT}

A leányvállalatok vagyonának regionális megoszlása 1990 és 2000 között (\%-ban) (The Geographic Distribution of Assets of Affiliates between 1990 and 2000)

\begin{tabular}{|c|c|c|c|c|c|c|c|c|c|c|c|}
\hline & 1990 & 1991 & 1992 & 1993 & 1994 & 1995 & 1996 & 1997 & 1998 & 199 & 2000 \\
\hline Világ & 100 & 100 & 100 & 100 & 100 & 100 & 100 & 100 & 100 & 100 & 10 \\
\hline Kanada & 14,6 & 13,9 & 12,5 & 11,0 & 9,8 & 9,1 & 9,2 & 8,8 & 8,0 & 8,3 & 8 \\
\hline Európa & 58,0 & 57,6 & 58,5 & 59,0 & 59,1 & 60,3 & 60,7 & 60,4 & 60,1 & 60,0 & 61,1 \\
\hline Belgium & 2,8 & 2,7 & 2,8 & 2,3 & 2,5 & 2,6 & 2,3 & 2,3 & 2,4 & 2,1 & 2,3 \\
\hline Norv & 0,8 & 0,7 & 0,7 & 0,7 & 0,6 & 0,5 & 0,6 & 0,5 & 0,5 & 0,5 & 0,5 \\
\hline Franc & 5,0 & 4,8 & 5,1 & 4,2 & 4,4 & 5,1 & 4,8 & 4,5 & 4,2 & 3,5 & 3,5 \\
\hline Ném & 8,2 & 8,2 & 8,2 & 7,4 & 7,6 & 7,8 & 6,8 & 6,1 & 6,5 & 6,3 & 5,6 \\
\hline fror & 1 & 1,2 & 1,3 & 1,4 & 1,6 & 1,7 & 1,7 & 1,9 & 2,1 & 2,3 & 2, \\
\hline Olas & & 3,1 & 2,7 & 2,1 & 2,2 & 2,2 & 2,1 & 1,9 & 1,9 & 1,6 & 1,5 \\
\hline & 5,6 & 5,9 & 5,7 & 5,3 & 5,4 & 5,1 & 5,5 & 5,9 & 6,6 & 1,0 & 7,4 \\
\hline Egy & 23,5 & 23,6 & 24,6 & 27,9 & 25,8 & 25,6 & 29,5 & 30,1 & 8,2 & 28,1 & 27,4 \\
\hline Eurc & 53,2 & 53,1 & 53,9 & 53,8 & 52,8 & 53,6 & 56,2 & 55,8 & 55,4 & 55,4 & 56,5 \\
\hline $\mathrm{Kel}$ & 0,0 & 0,1 & 0,2 & 0,3 & 0,4 & 0,5 & 0,6 & 0,6 & 0,8 & 19 & 0,9 \\
\hline & 0,0 & $0, I$ & 0,2 & 0,2 & 0,3 & 0,3 & 0,3 & 0,3 & 04 & 04 & \\
\hline Latin-A & 11,8 & 11,6 & 11,7 & 10,9 & 10,4 & 10,3 & 11,3 & 12,2 & 12,9 & 13,9 & 14,1 \\
\hline Dél- & 3,2 & 3,0 & 3,3 & 3,1 & 3,3 & 3,5 & 4,0 & 4,6 & 4,8 & 4,5 & 4,4 \\
\hline Bra & 1,9 & 1,7 & 1,8 & 1,6 & 1,6 & 1,7 & 2,0 & 2,3 & 2,6 & 2 & 2,2 \\
\hline & 2,0 & 2,3 & 2,4 & 2,4 & 2,2 & 1,7 & 2,2 & 2,4 & 2,6 & 6 & 2,6 \\
\hline & 1,1 & 1,2 & 1,4 & 1,4 & 1,3 & 1,1 & 1,2 & 1,4 & 1,6 & 8 & 1,9 \\
\hline & 6,5 & 6,3 & 6,0 & 5,4 & 4,8 & 5,0 & 5,2 & 5,2 & 5,6 & 8 & 7,1 \\
\hline Bah & 0,4 & 0,3 & 0,3 & 0,2 & 0,1 & 0,1 & 0,1 & 0,1 & 0,1 & 2 & 0,2 \\
\hline Ber & 3,3 & 3,4 & 3,3 & 3,2 & 2,8 & 3,1 & 2,9 & 3,2 & 3,2 & 3,7 & 3,9 \\
\hline Afr & 1,1 & 1,0 & 1,0 & 0,9 & 0,9 & 0,8 & 0,9 & 1,0 & 1,0 & 0,9 & 0,9 \\
\hline & 0,2 & 0,2 & 0,2 & 0,1 & 0,1 & 0,1 & 0,1 & 0,1 & 1 & 2 & 0,1 \\
\hline & 0,2 & 0,2 & 0,2 & 0,2 & 0,2 & 0,2 & 0,2 & 0,2 & 0,3 & 0,2 & 0,2 \\
\hline Dél & 0,1 & 0,1 & 0,1 & 0,1 & 0,1 & 0,2 & 0,2 & 0,2 & 0,2 & 0,2 & 0,2 \\
\hline Köz & 0,7 & 0,7 & 0,7 & 0,6 & 0,6 & 0,5 & 0,6 & 0,5 & 0,5 & 0,5 & $\underline{0,5}$ \\
\hline$\overline{\text { lzra }}$ & 0,2 & 0,1 & 1 & 0,1 & 0,1 & 0,1 & 0,1 & 0,1 & 1 & 0,1 & 0,2 \\
\hline & 0,1 & 0,1 & 0,1 & 0,1 & 0,1 & 0,1 & 0,2 & 0,1 & 0,1 & 0,1 & 0,1 \\
\hline & 0,2 & 0,2 & 0,2 & 0,1 & 0,1 & 0,1 & 0,1 & 0,1 & 0,0 & 0.1 & 0,1 \\
\hline Ázsia, & 12,8 & 14,4 & 14,9 & 16,7 & 18,6 & 18,4 & 16,6 & 16,7 & 17,1 & 16,2 & 15,3 \\
\hline Aus & 31 & 3,0 & 2,8 & 2,5 & 2,8 & 2,5 & 2,9 & 2,4 & 2,3 & 2,5 & 2,2 \\
\hline 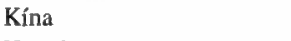 & 1 & 0,1 & 0,1 & 0,1 & 0,3 & 0,3 & 0,4 & 0,5 & 0,6 & 0,7 & 0,6 \\
\hline ongk & 2 & 1,2 & 3 & 1,7 & 2,4 & 2,8 & 1,7 & 1,9 & 1,7 & 1,7 & 1,8 \\
\hline & 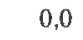 & 0,0 & 0,0 & 0,0 & 0,1 & 0,1 & 0,1 & 0,1 & 0,2 & 0,2 & 0,2 \\
\hline & 0,6 & 0,7 & 0,7 & 0,6 & 0,7 & 0,6 & 0,6 & 0.5 & 0.5 & 0.5 & 0,4 \\
\hline & 4,8 & 6,0 & 6,0 & 7,9 & 8,2 & 7,9 & 6,3 & 6,8 & 7,5 & 5,1 & 5,6 \\
\hline & 0 & 0,2 & 0,3 & 0,2 & 0,3 & 0,2 & 0,2 & 0,2 & 0,2 & 0,3 & 0,3 \\
\hline & 0,4 & 0,5 & 0,6 & 0,6 & 0,6 & 0,6 & 0,6 & 0,6 & 0,5 & 0,5 & 0,5 \\
\hline . & 0,2 & 0,2 & 0,2 & 0,2 & 0,2 & 0,3 & 0,3 & 0,2 & 0,3 & 0,2 & 0,2 \\
\hline Szingapúr & 1,0 & 1,0 & 1,3 & 1,5 & 1,6 & 1,6 & 1,7 & 1,8 & 1,6 & 1,8 & 1,8 \\
\hline Tajvan & 0,5 & 0,5 & 0,6 & 0,6 & 0,6 & 0,6 & 0,6 & 0,6 & 0,6 & 0,7 & 0,8 \\
\hline Thaifold & 0,3 & 0,4 & 0,4 & 0,5 & 0,5 & 0,5 & 0,5 & 0,4 & 0,4 & 0,4 & 0,4 \\
\hline OECD & 6,9 & 77,6 & 71 & 02 & & 8,47 & 77 & 6,5 & 76,9 & 7,17 & 7,2 \\
\hline "G7" tagok & 59,5 & 59,6 & 59,1 & 60,6 & 58,1 & 57,7 & 58,8 & 58,1 & 56,3 & 53,9 & 51,6 \\
\hline
\end{tabular}

Forrás: Bureau of Economic Analisys (BEA) alapján saját számítás. 
Az amerikai kontinens súlya az évtized folyamán mérséklődött, ennek hátterében a kanadai leányvállalatok számának jóval átlag alatti bővülése húzódik meg. Kanada a vagyon szerint is veszített jelentőségéből, a vizsgált időszak alatt az ország részesedése a leányvállalatok vagyonából közel a felére esett vissza. Az északi szomszédnál tapasztalt visszaesés elsősorban a szolgáltatási ágazatokat, döntöen a pénzügyi szférát, a kiskereskedelmi egységeket, valamint a villamos energia, gáz-, hö- és vízellátás területét érintette.

Latin-Amerika befektetési szempontból - mind a leányvállalatok számából való részesedést, mind pedig a vagyonból való részesedést alapul véve - a harmadik legfontosabb régiónak számít. A vizsgált időszakban a leányvállalatok $15 \%$-a müködött itt, és a régió a vagyonból való részesedését is növelte. A térségben müködö leányvállalatok többsége a legnagyobb piacot jelentö, ezért regionális összefüggésben is kezelt Dél-Amerikában létesült. Közép-Amerika majdnem egyharmad, a karibi térség egynegyed arányban részesült a leányvállalatok számából. Ugyanakkor a vagyonból való részesedést értékelve már a Karib-szigetek államainak dominanciája rajzolódik ki: a latin-amerikai vállalatok vagyonának fele ezen országokban koncentrálódott. Dél-Amerika a latin-amerikai vagyonból már csak egyharmad arányban, míg Közép-Amerika egyötöd arányban részesedett. Az egyes latinamerikai térségek vagyonból és a leányvállalatok számából való részesedésének alakulása arra enged következtetni, hogy a szigetvilágban a fejlettebb technológiai háttérrel rendelkezö és ezáltal nagyobb értékü leányvállalatok müködtek - amelyek részben a turizmusra, részben a "back-office" szolgáltatásokra, az "off-shore" pénzügyi tevékenységekre szakosodtak -, míg a kontinensen a munkaintenzív feldolgozó-ipari beruházások domináltak.

Latin-Amerikán belül, országok szintjén elemezve a folyamatokat egyértelmüen Mexikó szerepének felértékelődése mutatható ki: a NAFTA hatályba lépését követỏen a közép-amerikai államnak a latin-amerikai térségben létesített leányvállalatok számából és vagyonából való részesedése is jelentősen megnövekedett.

2000-ben Afrika és a Közel-Kelet részesedése a leányvállalatok számát tekintve együtt sem érte el a 4\%-ot, a vagyont alapul véve pedig az $1 \%$-ot, ráadásul mindkét térség pozíciója tovább gyengült. Emellett mindkét régióban igen magas területi és ágazati koncentráció volt mérhetö. Az Afrikában létesített leányvállalatok vagyonának $60 \%$-a, a közel-keleti egységek vagyonának közel harmada koncentrálódott az olajágazatban. Területi szempontból közelítve pedig megállapítható, hogy az Afrikában müködő leányvállalatok közel 60\%-a a Dél-Afrikai Köztársaságban, Egyiptomban és Nigériában található, $\mathrm{s}$ e három ország a vagyonnak is több mint felével rendelkezett. Ugyancsak magas területi koncentráció volt kimutatható a KözelKeleten is, ahol a leányvállalatok közel 80\%-a Szaúd-Arábiában, Izraelben és az Arab Emírségekben létesültt, s e vállalatok a vagyonnak is háromnegyedét birtokolták. 
Csiki Anita : Az amerikai transznacionális vállalatok térszerveződése az 1990-es években.

Tér és Társadalom 18. évf. 2004/3. 91-110. p.

TÉT XVIII. évf. 2004 - 3

Kitekintő

97

\section{A leányvállalatok iparágak szerinti térszervezödése}

A tanulmány ezen része az amerikai vállalatok iparágak szerinti térszerveződésének felvázolására tesz kísérletet. Mivel a BEA statisztikájának ágazati szintü besorolása 1998-tól jelentősen módosult, az időbeni összehasonlíthatóság érdekében, valamint terjedelmi kötöttségek miatt az ágazati folyamatok elemzése az 1990 és 1998 közötti időszakra terjed ki (3.,4. és 5. táblázat).

1990 és 1998 között évi átlagban 5\%-kal növekedett a leányvállalatok száma, és 20\%-kal bővült ezen vállalatok vagyona. Átlag feletti növekedést a föbb besorolás szerint a nagykereskedelmi, a pénzügyi, az egyéb szolgáltató szféra, valamint a jármügyártás és a gépipar egyes területeinél (motorok és turbinák, háztartási audiovizuális eszközök) volt kimutatható, míg a primer szektor és a feldolgozóipar legtöbb ága veszített súlyából.

A BEA adatai szerint az amerikai TNC-k ágazati megoszlását tekintve a kilencvenes évek végén a feldolgozóipar 36\%-kal, a kitermelőipar 4\%-kal, a nagykereskedelem 23\%-kal, a szolgáltatási és egyéb szféra 37\%-kal részesedett a leányvállalatok számából. A szolgáltatásokat és az egyéb ágazatokat azonban nehéz elkülönítve kezelni, hiszen az egyéb kategóriába szolgáltatási jellegü tevékenységek is besorolásra kerültek, e csoporton belül a tisztán szolgáltató tevékenység aránya meghaladta a 70\%-ot. Még inkább kirajzolódik az egyes ágazatok jelentősége a vagyon szerinti megoszlást alapul véve: a kilencvenes évek végén a feldolgozóipar $23 \%$-kal, a kitermelöipar 4\%-kal, a nagykereskedelem $8 \%$-kal, a szolgáltatási és egyéb szféra $65 \%$-kal részesedett a leányvállalatok összesített vagyonából.

Az elemzés a továbbiakban a legfontosabb ágazatok térszerveződésének időbeni alakulását vázolja fel. A 20. század utolsó évtizedében tovább folytatódott az igen magas szinten globalizálódott olajágazat jelentőségének mérséklődése. A tőkekoncentrált szektorra nagyfokú területi koncentráció jellemző: az ágazaton belül a szektor vagyonának fele öt államban (Kanada, Egyesült Királyság, Norvégia, Ausztrália, Indonézia) összpontosult. Bár a kitermelöipar területi megoszlását mindenekelött az erőforrások területi megoszlása határozza meg, de a piaci és a politikai viszonyok is jelentős lokalizációs tényezöként jelennek meg. Az elmúlt években az ágazat térszervezödésében kimutatható változások következtek be. Mivel a közelkeleti kormányok nagyobb beleszólási jogot vívtak ki országaik olajforrásának hasznosítása felett, az amerikai jelenlét a térségben folyamatosan mérséklódött. Ez, valamint a fejlett államok szénhidrogénforrásainak kimerülése, az ottani kitermelési költségek növekedése, a súlyosbodó környezeti problémák, valamint az új források megjelenése együttesen eredményezték azt, hogy a kitermelés növekvő mértékben tolódott és tolódik át a kevésbé fejlett, illetve fejlődó országokba. A statisztika is ezt támasztja alá, hiszen 1990-ben még a szektor vagyonának több mint 70\%-át a fejlett államokat tömörítő OECD-országok birtokolták, addig 1998-ban már „csak” 60\%-os volt ugyanezen államok részesedése. Ezzel egy időben az amerikai olajcégek érdekeltségeiket Latin-Amerikában, Afrikában, Ázsiában és Kelet-Európában (lényegében a szovjet utódállamokban) növelték. Afrika e szektort tekintve igen komoly szerepet tölt be az amerikai vállalatok érdekszférájában, hiszen az összes olajipari amerikai 
Csiki Anita : Az amerikai transznacionális vállalatok térszerveződése az 1990-es években.

Tér és Társadalom 18. évf. 2004/3. 91-110. p.

$98 \quad$ Kitekintő

TÉT XVIII. évf. 2004

befektetés vagyonának több mint $8 \%$-a létesült a kontinensen, ráadásul az afrikai leányvállalatok vagyonának $60 \%$-a is ebben az ágazatban müködött.

A kilencvenes évek folyamán a feldolgozóipar is veszített súlyából. Bár az ágazatra továbbra is jellemző a magas fokú területi koncentráció, a vizsgált időszak alatt a fejlett államok vagyonból való részesedése tovább csökkent. A feldolgozóiparon belül a legnagyobb súlyt a jármügyártás, a vegyipar, a gépipar és az élelmiszeripar képviseli, ezért ezekről részletesen is szólunk.

Az amerikai vállalatok a tárolási, tartósítási és szállítási technológiák fejlődésének köszönhetően már a mezögazdaság és annak termékeit feldolgozó ipar terén is egyre magasabb szinten nemzetköziesedettek. Mivel a fejlett ipari államokban a piacok lassan bővülnek, a társaságok érdekeltségeiket egyre inkább a közepes jövedelmü országokban növelik majd, ezt a tendenciát már részben jelzi is Kanada és Európa csökkenő - bár még mindig jelentős - részesedése, valamint Mexikó és az egész latin-amerikai régió szerepének felértékelödése.

A feldolgozóiparon belül igen komoly súlyt képvisel a vegyipar, ahol az összes feldolgozó-ipari leányvállalat több mint ötöde müködött. Igaz ugyan, hogy az ágazat jelentösége összességében csökkent, a feldolgozóiparon belüli pozíciója mégis erösödött. 1998-ban a vegyiparon belül a vállalatok közel 30\%-át az ipari vegyszereket elöállító üzemek, negyedét a gyógyszergyárak tették ki, míg további egyötöd arányban a kozmetikai és a háztartási vegyi árukat előállító ágazat részesedett. Amennyiben azonban a vagyon alapján nézzük az egyes ágazatok súlyát, a sorrend másként alakult: a vegyipari vagyon $40 \%$-át a gyógyszeripari termékeket, további harmadát az ipari kemikáliákat előállító egységek vagyona jelentette. A vizsgált időszakban a vegyiparon belül mind az ipari kemikáliák gyártásával, mind a kozmetikai és háztartási vegyi áruk előállításával foglalkozó cégek pozíciója gyengült, miközben a gyógyszeripar a feldolgozóiparon és a vegyiparon belül is erősítette helyzetét. Az amerikai gyógyszeripari vállalatok versenytársaikkal összevetve is igen meggyőzỏ nemzetközi fölénnyel rendelkeznek: az UNCTAD által összeállított top 100 vállalat listájára felkerült kilenc gyógyszeripari cégböl például háromnak, míg a tizenöt vezetỏ gyógyszeripari társaság közül kilencnek volt a headquartere az Egyesült Államokban (Simai 2000, 92-93).

A kilencvenes évek folyamán a vegyiparban hatalmas nemzetközi fúziókkal kísért racionalizálási folyamat zajlott le, ami tovább növelte az ágazat koncentrációját. Az átszervezések természetesen hatással voltak az ágazat térszerveződésére is. A fejlett ipari országokban az ésszerüsítés érdekében a felesleges kapacitásokat leépítették, a környezetet súlyosabban terhelö ágazatokat kitelepítették oda, ahol a környezetvédelmi szabályok kevésbé voltak szigorúak, így a vállalatok termeléseik egy részét Latin-Amerikában, Kínában és más ázsiai államokban terítették szét. Ezzel párhuzamosan a fejlett államok részesedése tovább apadt. És bár a vegyipari ágazatok még ma is elsősorban a fejlettebb államokban koncentrálódnak, ezek az államok vezető szerepüket döntően a gyógyszeripar, valamint a kozmetikai és a háztartási vegyipar bövülésének köszönhetik. Az Európai Unió magas részesedéséhez a fent említett ágazatok növekvő szerepe mellett az is hozzájárult, hogy a belső piac védelmében rendkívül magas vámot vetettek ki az olcsó vegyipari importárura. 
Csiki Anita : Az amerikai transznacionális vállalatok térszerveződése az 1990-es években.

Tér és Társadalom 18. évf. 2004/3. 91-110. p.

TÉT XVIII. évf. 2004 - 3

Kitekintö

99

\section{TÁBLÁZAT}

A leányvállalatok iparági megoszlása 1990 és 1998 között (\%-ban)

(The Industry Distribution of Affiliates between 1990 and 1998)

\begin{tabular}{|c|c|c|c|c|c|c|c|c|c|}
\hline & 1990 & 1991 & 1992 & 1993 & 1994 & 1995 & 1996 & 1997 & 1998 \\
\hline \multicolumn{10}{|c|}{ Részesedés a leányvállalatok számából (összes=100\%) } \\
\hline Olajágazat & 7,3 & 7,3 & 7,4 & 7,0 & 6,4 & 6,4 & 6,5 & 6,5 & 6,5 \\
\hline Feldolgozóipar & 41,0 & 40,7 & 40,5 & 40,6 & 36,7 & 37,0 & 37,1 & 37,1 & 36,6 \\
\hline Élelmiszeripar & 3,6 & 3,5 & 3,7 & 4,0 & 3,5 & 3,4 & 3,3 & 3,2 & 3,2 \\
\hline Vegyipar & 10,2 & 10,0 & 10,0 & 9,8 & 8,4 & 8,6 & 8,8 & 8,7 &, 5 \\
\hline Ipari kemikáliák & 2,6 & 2,6 & 2,5 & 2,5 & 2,3 & 2,4 & 2,5 & 2,5 & 2,4 \\
\hline Gyógyszergyártás & 3,0 & 2,9 & 2,9 & 2,8 & 2,2 & 2,1 & 2,2 & 2,2 & 2,1 \\
\hline Kozmetikai és háztartási vegyi áruk & 2,1 & 2,1 & 2,1 & 2,2 & 1,7 & 1,8 & 1,8 & 1,7 & 1,6 \\
\hline Fémipar & 3,7 & 3,6 & 3,6 & 3,6 & 3,3 & 3,4 & 3 & 3,2 & 3,1 \\
\hline Gépipar & 10,6 & 10,5 & 10,2 & 10,1 & 8,9 & 9,0 & 9 & 1 &, 0 \\
\hline Számítästechnikai és irodai eszköz & 1,0 & 0.9 & 0,9 & 0.8 & 0,7 & 0.7 & 0.7 & 0.7 & 0,7 \\
\hline Eelekıronikai berendezések & 4,7 & 4,7 & 4,6 & 4,6 & 4,1 & 4,1 & 4,1 & 4,1 & 4,1 \\
\hline Jármügyártás & 2,1 & 2,1 & 2,1 & 2,1 & 1,9 & 2,1 & 2,2 & 2,3 & 2,5 \\
\hline Autóipar & 1,8 & 1,8 & 1,8 & 1,8 & 1,6 & 1,8 & 1,9 & 2,0 & 2,2 \\
\hline Nagykeresl & 24,4 & 24,2 & 24,1 & 24,2 & 25,5 & 24,7 & 24,2 & 23,7 & 23,1 \\
\hline Tartós áruk & 15,9 & 15,9 & 15,7 & 15,5 & 16,4 & 15,8 & 15,4 & 15,1 & 14,6 \\
\hline Professzionális felsz & 6,1 & 6,1 & 6,0 & 6,0 & 6,5 & 6,2 & 6,0 & 5,9 & 6,0 \\
\hline Pénzìgy és & 13,0 & 13,1 & 13,1 & 13,3 & 12,7 & 13,1 & 13,5 & 13,8 & 14,9 \\
\hline Egyéb szolgáltatások & 9,1 & 9,2 & 9,3 & 9,4 & 12,2 & 12,3 & 12,2 & 12,4 & 12,3 \\
\hline Úzleti sza & 4,3 & 4,5 & 4,4 & 4,5 & 6,5 & 6,6 & 6.5 & 6,6 & 6,6 \\
\hline Reklám & & 2 , & 2 & 2 & & & & 3,5 &, 4 \\
\hline Adatfe & 0,7 & 0,7 & 0 , & 0 , & 0 , & & & 1,8 & 0,8 \\
\hline Menedzs & 1,1 & 1,1 & 1,1 & 1,1 & 1,3 & 1,3 & 1,3 & 1,3 & 1,3 \\
\hline Foyáb & 5,1 & 5,5 & 5,6 & 5,7 & 6,5 & 6,5 & 6,5 & 6,5 & 6,6 \\
\hline \multicolumn{10}{|c|}{ Részesedés a leányvállalatok vagyonából (összes $=100 \%$ ) } \\
\hline zat & 13,3 & 12,5 & 12,1 & 10,4 & 9,5 & 8,4 & 8,4 & 8,0 & 7,3 \\
\hline Feldo & 34,6 & 33,3 & 32,2 & 27,7 & 26,7 & 26,3 & 26,9 & 25,3 & 24,2 \\
\hline Élelm & 3,5 & 3,6 & 3 & 3, & 3,2 & 3, & 2,9 & 2,8 & 2,8 \\
\hline Vegs & 7,5 & 7,2 & 7 & 6 , & 6,0 & 6 , & 7,0 & 6,5 & 6,1 \\
\hline liák & 3,1 & 3.1 & 2,9 & 2,3 & 2,5 & 2,3 & 2,5 & 2,3 & 2,1 \\
\hline rtás & 2,3 & 2,1 & 2,3 & 1,8 & 1,8 & 2,2 & 2,7 & 2,5 & 2,5 \\
\hline rási vegy & 1,1 & 1,1 & 1,3 & 1,1 & 1.0 & 1,1 & 1,1 & 0,9 & 0,7 \\
\hline Fém & 1,7 & 1,5 & 1,5 & 1,3 & 1,3 & 1,2 & 1,4 & 1,3 & 1,3 \\
\hline Gépipar & 9,2 & 8,9 & 8,2 & 7,1 & 6.7 & 6,7 & 6,5 & 6,3 & 5,9 \\
\hline Számítástechnil & 4,3 & 4,4 & 3,9 & 3,3 & 3,0 & 2,8 & 2,3 & 2,2 & 1,9 \\
\hline Elektronikai be & 2,8 & 2,7 & 2,6 & 2,4 & 2,3 & 2,5 & 2,6 & 2,6 & 2,5 \\
\hline Jármủgyártás & 5,7 & 5,3 & 4,8 & 4,0 & 3,9 & 3,8 & 3,8 & 3,6 & 3,4 \\
\hline Autóipar & 5.4 & 5,1 & 4,6 & 3,9 & 3,7 & 3,6 & 3,6 & 3,4 & 3,2 \\
\hline Nagykereske & 9,53 & 9,12 & 9,19 & 8,61 & 7,70 & 8,07 & 7,72 & 7,30 & 6,70 \\
\hline Tartös áruk & 6.4 & 6,1 & 5,9 & 5,4 & 5,2 & 5,1 & 4,7 & 4,3 & 4,1 \\
\hline Professzion & 3,6 & 3,31 & 3,35 & 3,07 & 3,00 & 2,96 & 2,73 & 2,49 & 2,39 \\
\hline Pénziuggy és biztosítás & 34,3 & 36,0 & 37,5 & 45,6 & 46,7 & 48,7 & 47,9 & 49,3 & 50,8 \\
\hline Egyéb szolgáltatások & 3,5 & 3,9 & 4,0 & 3,3 & 4,1 & 4,1 & 4,2 & 4,7 & 5,1 \\
\hline Ũzleti szolgáltatások & 1,6 & 2,2 & 2,2 & 1,7 & 2,2 & 2,1 & 2,3 & 2,8 & 3,1 \\
\hline Reklám & 0,4 & 0,5 & 0,4 & 0,3 & 0,4 & 0,4 & 0,4 & 0,4 & 0,5 \\
\hline Adatfeldolgozás & 0.1 . & 0,2 & 0,2 & 0,2 & 0,2 & 0,3 & 0,3 & 0,3 & 0,3 \\
\hline Menedzsmentszolgáltatások & 0,5 & 0,4 & 0,4 & 0,3 & 0,3 & 0,4 & 0,4 & 0,4 & 0,4 \\
\hline Egyéb & 4,7 & 5,1 & 5,1 & 5,4 & 6,2 & 4,5 & 5,1 & 5,4 & 5,9 \\
\hline
\end{tabular}

Forrás: Bureau of Economic Analisys (BEA) alapján saját számítás. 
Csiki Anita : Az amerikai transznacionális vállalatok térszerveződése az 1990-es években.

Tér és Társadalom 18. évf. 2004/3. 91-110. p.

100 Kitekintö

TÉT XVIII. évf. 2004

4. TÁBLÁZAT

A leányvállalatok vagyonának iparágak szerinti területi megoszlása, 1998 (\%-ban)

(The Geographic Distribution of Assets of Affiliates by Industry, 1998)

\begin{tabular}{|c|c|c|c|c|c|c|c|c|c|c|c|}
\hline Világ $=100 \%$ & 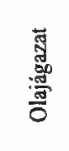 & 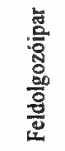 & 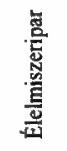 & 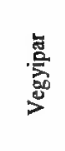 & 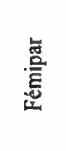 & $\begin{array}{l}\text { 总 } \\
\text { 歖 } \\
\text { 喜 }\end{array}$ & 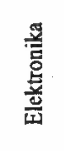 & 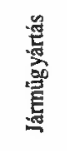 & 总惫 & 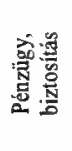 & 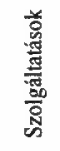 \\
\hline Kanada & 14,7 & 10,9 & 9,8 & 7,4 & 13,4 & 5,0 & 6,0 & 24,5 & 6,6 & 5,7 & 6,8 \\
\hline Európa & 39,2 & 59,6 & 57,4 & 64,2 & 68,3 & 63,3 & 46,0 & 55,0 & 67,8 & 63,7 & 68,3 \\
\hline Belgium & 0,8 & 3,1 & 3,1 & 7,1 & 2,7 & 1,1 & 1,0 & 1,2 & 4,6 & 1,4 & 10,6 \\
\hline Norvégia & 4,5 & 0,2 & 0,0 & 0,1 & 0,2 & 0,4 & 0,0 & 0,0 & 0,5 & 0,1 & 0,3 \\
\hline Franciaország & 1,0 & 7,4 & 5,6 & 8,1 & 18,8 & 9,5 & 4,7 & 3,1 & 7,6 & 2,7 & 6,8 \\
\hline Németország & 3,3 & 11,6 & 6,7 & 6,8 & 11,1 & 14,2 & 8,9 & 23,9 & 5,5 & 5,3 & 4,6 \\
\hline Îrország & 0,4 & 3,3 & 3,1 & 4,5 & 0,7 & 4,0 & 5,1 & 0,1 & 0,7 & 2,1 & 3,6 \\
\hline Olaszország & 0,0 & 4,1 & 2,0 & 4,4 & 4,5 & 5,4 & 4,8 & 2,6 & 4,3 & 0,5 & 5,0 \\
\hline Hollandia & 3,0 & 5,5 & 6,7 & 9,2 & 2,7 & 2,9 & 3,4 & 1,6 & 9,8 & 7,8 & 5,6 \\
\hline Egyesült Királyság & 20,8 & 15,8 & 20,9 & 16,5 & 15,9 & 21,3 & 10,8 & 14,1 & 8,8 & 37,8 & 24,7 \\
\hline Európai Unió (15) & 31,4 & 56,5 & 54,0 & 61,8 & 65,5 & 61,2 & 43,5 & 53,6 & 48,4 & 60,0 & 64,4 \\
\hline Kelet-Európa & 2,7 & 1,3 & 1,9 & 0,8 & 1,5 & 0,7 & 1,2 & 1,3 & 1,1 & 0,3 & 0,5 \\
\hline Latin-Amerika & 9,5 & 13,0 & 21,6 & 12,9 & 9,6 & 6,0 & 12,3 & 15,5 & 7,2 & 13,7 & 8,2 \\
\hline Dél-Amerika & 6,4 & 8,4 & 11,7 & 9,5 & 7,4 & 2,7 & 8,8 & 8,4 & 3,6 & 2,0 & 3.7 \\
\hline Brazilia & 1,4 & 5,8 & 6,1 & 6,1 & 5,7 & 2,4 & 8,6 & 5,2 & 1,2 & 1,0 & 2,0 \\
\hline Közép-Amerika & 0,8 & 4,3 & 9,7 & 3,0 & 0,0 & 3,3 & 3,0 & 7,1 & 1,9 & 2,1 & 1,7 \\
\hline Mexikó & 0,2 & 4,0 & 9,1 & 2,8 & 1,4 & 0,0 & 0,0 & 7,1 & 1,0 & 0,6 & 1,0 \\
\hline Karib-szigetek & 2,3 & 0,3 & 0,1 & 0,4 & 0,0 & 0,0 & 0,5 & 0,0 & 1,7 & 9,6 & 2,8 \\
\hline Bahama-szigetek & 0,0 & 0,0 & 0,0 & 0,0 & 0,0 & 0,0 & 0,0 & 0,0 & 0,0 & 0,1 & 0,1 \\
\hline Bermuda-szigetek & 0.3 & 0,0 & 0,0 & 0,0 & 0,0 & 0,0 & 0,0 & 0,0 & 1,5 & 5,9 & 1,8 \\
\hline $\begin{array}{l}\text { Az Egyesült Királyság } \\
\text { fennhatósága alatt álló } \\
\text { Karib-szigetek }\end{array}$ & 0.1 & 0,1 & 0,0 & 0,0 & 0,0 & 0,0 & 0,0 & 0,0 & 0,1 & 2,5 & 0,6 \\
\hline Afrika & 8,4 & 0,6 & 0,6 & 1,1 & 0,9 & 0,2 & 0,4 & 0,2 & 0,6 & 0,3 & 0,6 \\
\hline Egyiptom & 1,1 & 0,1 & 0,0 & 0,0 & 0,0 & 0,1 & 0,0 & 0,0 & 0,1 & 0,0 & 0,1 \\
\hline Nigéria & 2,4 & 0,0 & 0,0 & 0,0 & 0,0 & 0,0 & 0,0 & 0,0 & 0,0 & 0,1 & 0,0 \\
\hline Dél-Afrikai Köztársaság & 0,0 & 0,3 & 0,0 & 0,8 & 0,2 & 0,1 & 0,4 & 0,0 & 0,3 & 0,1 & 0,5 \\
\hline Közel-Kelet & 2,2 & 0,4 & 0,3 & 0,1 & 0,1 & 0,1 & 2,9 & 0,0 & 0,2 & 0,2 & 0,8 \\
\hline Izrael & 0,0 & 0,4 & 0,0 & 0,1 & 0,1 & 0.1 & 2,9 & 0,0 & 0,0 & 0,0 & 0,3 \\
\hline Szaúd-Arábia & 0,1 & 0,0 & 0,0 & 0,0 & 0,0 & 0,0 & 0,0 & 0,0 & 0,0 & 0,0 & 0,3 \\
\hline Arab Emírségek & 0,4 & 0,0 & 0,0 & 0,0 & 0,0 & 0,0 & 0,0 & 0,0 & 0,1 & 0,0 & 0,1 \\
\hline Ázsia, Ausztrália és Óceánia & 23,1 & 15,5 & 10,3 & 14,3 & 7,7 & 25,4 & 32,4 & 4,8 & 17,7 & 16,4 & 15,3 \\
\hline Ausztrália & 5,4 & 2,2 & 3,8 & 3,2 & 1,5 & 0,9 & 0,3 & 2,7 & 2,2 & 1,1 & 3,1 \\
\hline Kína & 1,1 & 1,4 & 0,8 & 1,2 & 1,4 & 1,8 & 4,1 & 0,3 & 0,5 & 0,1 & 0,3 \\
\hline Hongkong & 0,5 & 0,7 & 0,0 & 0,3 & 0,0 & 0,2 & 3,0 & 0,1 & 4,5 & 1,7 & 1,3 \\
\hline India & 0,2 & 0,3 & 0,5 & 0,3 & 0,0 & 0,5 & 0,1 & 0,2 & 0,2 & 0,1 & 0,1 \\
\hline Indonézia & 4,4 & 0,1 & 0,1 & 0,2 & 0,0 & 0,1 & 0,1 & 0,0 & 0,0 & 0,0 & 0,1 \\
\hline Japán & 0,0 & 3,1 & 2,8 & 4,9 & 1,0 & 1,5 & 6,2 & 0,3 & 5,6 & 11,0 & 8,6 \\
\hline Dél-Korea & 0,0 & 0,5 & 0,3 & 0,3 & 0,2 & 0,3 & 0,9 & 0,2 & 0,7 & 0,0 & 0,3 \\
\hline Malajzia & 1,7 & 1,1 & 0,1 & 0,4 & 0,0 & 1,6 & 5,9 & 0,0 & 0,2 & 0,2 & 0,2 \\
\hline Fúlöp-szigetek & 0,0 & 0,4 & 0,5 & 0,3 & 0,0 & 0,0 & 1,9 & 0,0 & 0,2 & 0,2 & 0,1 \\
\hline Szingapúr & 2,5 & 3,8 & 0,1 & 1,9 & 0,2 & 16,6 & 6,8 & 0,4 & 2,4 & 0,7 & 0,6 \\
\hline Tajvan & 0,0 & 0,6 & 0,2 & 0,9 & 0,2 & 0,3 & 2,3 & 0,0 & 0,7 & 0,8 & 0,2 \\
\hline Thaiföld & 2,1 & 0,5 & 0,4 & 0,3 & 0,3 & 1,5 & 0,6 & 0,0 & 0,2 & 0,3 & 0,0 \\
\hline OECD & 59,0 & 85,0 & 83,0 & 85,0 & 85,0 & 88,0 & 74,0 & 80,0 & 90,0 & 85,0 & 90,0 \\
\hline "G7" tagok & 39,9 & 53,0 & 47,9 & 48,1 & 64,8 & 56,9 & 41,5 & 68,5 & 38,3 & 63,0 & 56,5 \\
\hline
\end{tabular}

Forrás: Bureau of Economic Analisys (BEA) alapján saját számítás. 
Csiki Anita : Az amerikai transznacionális vállalatok térszerveződése az 1990-es években.

Tér és Társadalom 18. évf. 2004/3. 91-110. p.

TÉT XVIII. évf. 2004 @ 3

Kitekintö

101

\section{TÁBLÁZAT}

A leányvállalatok vagyonának iparágak szerinti területi megoszlása, 1990

(The Geographic Distribution of Assets of Affiliates by Industry, 1990)

\begin{tabular}{|c|c|c|c|c|c|c|c|c|c|c|c|}
\hline Világ $=100 \%$ & 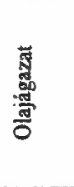 & 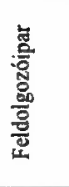 & 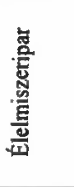 & 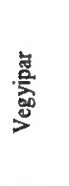 & 总 & 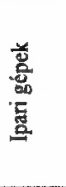 & 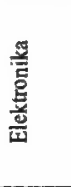 & 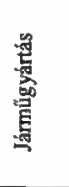 & 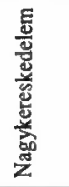 & 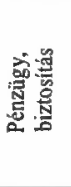 & 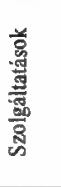 \\
\hline Kanada & 19,0 & 15,0 & 13,2 & 10,8 & 24,4 & 6,9 & 11,4 & 21,9 & 8,8 & 12,8 & 12,2 \\
\hline Európa & 45,6 & 63,8 & 64,8 & 67,7 & 52,5 & 70,6 & 50,9 & 64,5 & 65,3 & 56,7 & 70,1 \\
\hline Belgium & 1,3 & 3,5 & 2,1 & 7,8 & 2,2 & 1,7 & 2,0 & 0,0 & 5,0 & 1,6 & 9,8 \\
\hline Norvégia & 4,9 & 0,1 & 0,0 & 0,1 & 0,0 & 0,1 & 0,0 & 0,0 & 1,0 & 0,1 & 0,0 \\
\hline Franciaország & 2,0 & 8,3 & 6,3 & 12,4 & 5,8 & 10,9 & 7,7 & 1,9 & 10,4 & 1,4 & 6,3 \\
\hline Németország & 4,9 & 14,1 & 8,8 & 10,5 & 16,9 & 15,2 & 10,6 & 26,1 & 5,8 & 4,4 & 8,0 \\
\hline Írország & 0,2 & 2,3 & 3,0 & 2,7 & 1,1 & 3,1 & 2,6 & 0,1 & 0,3 & 0,8 & 0,0 \\
\hline Olaszország & 0,0 & 6,1 & 5,8 & 6,8 & 2,8 & 11,3 & 5,0 & 3,1 & 5,9 & 0,8 & 2,9 \\
\hline Hollandia & 3,2 & 5,0 & 5,2 & 8,7 & 5,2 & 5,3 & 4,4 & 0,2 & 5,1 & 7,3 & 9,5 \\
\hline Egyesültt Királyság & 23,7 & 17,1 & 18,7 & 13,7 & 14,2 & 18,2 & 12,0 & 22,9 & 10,8 & 33,9 & 24,4 \\
\hline Európai Unió (15) & 37,2 & 60,9 & 56,1 & 66,7 & 50,9 & 68,0 & 48,1 & 62,8 & 48,5 & 51,3 & 65,0 \\
\hline Kelet-Európa & 0,0 & 0,0 & 0,0 & 0,0 & 0,0 & 0,0 & 0,0 & 0,0 & 0,0 & 0,0 & 0,0 \\
\hline Latin-Amerika & 5,5 & 8,9 & 11,5 & 8,4 & 15,7 & 6,3 & 7,6 & 9,5 & 5,2 & 19,3 & 5,4 \\
\hline Dél-Amerika & 2,8 & 6,2 & 7,6 & 5,9 & 12,3 & 5,5 & 5,1 & 4,6 & 2,0 & 0,6 & 1,1 \\
\hline Brazilia & 1,0 & 4,7 & 4,0 & 3,6 & 8,3 & 5,2 & 4,7 & 3,9 & 0.3 & 0,2 & 0,6 \\
\hline Közép-Amerika & 0,8 & 2,6 & 3,8 & 2,3 & 0,0 & 0,0 & 2,3 & 4,9 & 1,4 & 2,1 & 1,0 \\
\hline Mexikó & 0,0 & 2,4 & $3, I$ & 1,9 & 1,4 & 0,0 & 2,2 & 4,9 & 0,9 & 0,4 & 0.5 \\
\hline Karib-szigetek & 1,8 & 0,2 & 0,1 & 0,2 & 0,0 & 0,0 & 0,1 & 0,0 & 1,8 & 16,6 & 3,4 \\
\hline Bahama-szigetek & 0,1 & 0,0 & 0,0 & 0,0 & 0,0 & 0,0 & 0,0 & 0,0 & 0,2 & 0,8 & 1,8 \\
\hline Bermuda-szigetek & 0,8 & 0,0 & 0,0 & 0,0 & 0,0 & 0,0 & 0,0 & 0,0 & 1,1 & 8,8 & 0,5 \\
\hline $\begin{array}{l}\text { Az Egyesiut Királyság } \\
\text { fenhnatósaga alant álló } \\
\text { Karib-szigetek }\end{array}$ & 0,1 & 0,0 & 0,0 & 0,0 & 0,0 & 0,0 & 0,1 & 0.0 & 0,0 & 1,1 & 0,1 \\
\hline Afrika & 6,4 & 0,4 & 0,7 & 0,6 & 1,5 & 0,3 & 0,1 & 0,0 & 0,5 & 0,1 & 0,7 \\
\hline Egyiptom & 1,5 & 0,0 & 0,1 & 0,1 & 0,0 & 0,0 & 0,0 & 0,0 & 0,1 & 0,0 & 0,1 \\
\hline Nigéria & 1,7 & 0,0 & 0,1 & 0,0 & 0,0 & 0,0 & 0,0 & 0,0 & 0,0 & 0,0 & 0,0 \\
\hline Dél-Afrikai Köztársaság & 0,0 & 0,2 & 0,1 & 0,3 & 0,5 & 0,2 & 0,0 & 0,0 & 0,2 & 0,0 & 0,1 \\
\hline Közel-Kelet & 3,0 & 0,2 & 0,1 & 0,1 & 0,0 & 0,0 & 1,6 & 0,0 & 0,2 & 0,5 & 1,6 \\
\hline lzrael & 0,0 & 0,2 & 0,0 & 0,1 & 0,0 & 0,0 & 1,6 & 0,0 & 0,0 & 0,2 & 0,7 \\
\hline Szaúd-Arábia & 0,1 & 0,0 & 0,0 & 0,0 & 0,0 & 0,0 & 0,0 & 0,0 & 0,1 & 0,0 & 0,7 \\
\hline Arab Emirségek & 1,4 & 0,0 & 0,0 & 0,0 & 0,0 & 0,0 & 0,0 & 0,0 & 0,1 & 0,0 & 0,1 \\
\hline Ázsia, Ausztrália és Óceánia & 16,5 & 11,7 & 9,7 & 12,5 & 5,9 & 15,9 & 28,3 & 4,1 & 20,1 & 10,6 & 10,0 \\
\hline Ausztrália & 4,6 & 3,1 & 5,2 & 4,7 & 2,8 & 1.6 & 2,1 & 2,8 & 4,9 & 1,6 & 4,4 \\
\hline Kína & 0,3 & 0,1 & 0,1 & 0,1 & 0,0 & 0,0 & 0,2 & 0,0 & 0,2 & 0,0 & 0,0 \\
\hline Hongkong & 0,4 & 0,6 & 0,0 & 0,3 & 0,0 & 0,7 & 1,8 & 0,0 & 3,2 & 1,2 & 1,3 \\
\hline India & 0,0 & 0,1 & 0,0 & 0,1 & 0,0 & 0,0 & 0,0 & 0,0 & 0,0 & 0,0 & 0,0 \\
\hline Indonézia & 3,8 & 0,1 & 0,0 & 0,2 & 0,0 & 0,0 & 0,0 & 0,0 & 0,1 & 0,0 & 0,0 \\
\hline Japán & 2,2 & 4,1 & 2,3 & 4,7 & 1,4 & 8,1 & 6,8 & 0,2 & 8,2 & 6,4 & 2,2 \\
\hline Dél-Korea & 0,0 & 0,4 & 0,4 & 0,4 & 0,1 & 0,1 & 1,4 & 0,1 & 0,6 & 0,1 & 0,2 \\
\hline Malajzia & 1,5 & 0,5 & 0,0 & 0,1 & 0,1 & 0,0 & 4,1 & 0,0 & 0,2 & 0,0 & 0,0 \\
\hline Fülöp-szigetek & 0,0 & 0,3 & 0,8 & 0,4 & 0,0 & 0,0 & 0,8 & 0,0 & 0,1 & 0,0 & 0,4 \\
\hline Szingapúr & 1,8 & 1,4 & $0,1 \%$ & 0,5 & 0,3 & 3,6 & 5,9 & 0,0 & 1,3 & 0,3 & 0,9 \\
\hline Tajvan & 0,0 & 0,8 & 0,3 & 0,6 & 0,2 & 0,9 & 4,1 & 0,0 & 0,5 & 0,4 & 0,2 \\
\hline Thaiföld & 0,8 & 0,3 & 0,3 & 0,3 & 0,0 & 0,6 & 0,0 & 0,0 & 0,3 & 0,0 & 0,0 \\
\hline OECD & 71,7 & 91,5 & 81,4 & 91,1 & 82,3 & 92,4 & 86,9 & 91,1 & 93,8 & 79,8 & 90,6 \\
\hline "G7" tage & 51,8 & 64,7 & 55,1 & 58,9 & 65,5 & 70,4 & 53,6 & 76,1 & 49,8 & 59,7 & 56,1 \\
\hline
\end{tabular}

Forrás: Bureau of Economic Analisys (BEA) alapján saját számítás. 
Csiki Anita : Az amerikai transznacionális vállalatok térszerveződése az 1990-es években.

Tér és Társadalom 18. évf. 2004/3. 91-110. p.

A fémipar még mindig túltermeléssel, valamint kihasználatlan kapacitással küszködik. Ennek ellenére az ágazat pozíciója - bár részesedése a feldolgozóiparon belül a leányvállalatok számát tekintve visszaesett - a vagyont alapul véve tovább erősödött, melynek fö okai a koncentráció irányába ható fúziók és racionalizálási intézkedések voltak. Az amerikai nemzetközi fémipari befektetések alakulása azt jelzi, hogy az EU-n kívüli fejlettebb államoknak és Latin-Amerikának is csökkent a szektor vagyonából való részesedése, miközben a termelés a kevésbé fejlett ázsiai államokba helyezödött át. Országos szinten egyértelmủen Kína szerepe értékelödött fel, amely nemcsak olcsó munkaeröbázisa miatt vonzza ezeket a befektetéseket, de - mint a leginkább növekvő és hatalmas piacot jelentő gazdaság - fémipari nyersanyagok és termékek iránt is hatalmas keresletet támaszt. Az ágazat piacát erősen védö EU-ban azonban az amerikai vállalatok helyben termelve igyekeznek piachoz jutni, éppen ez lehet a magyarázata annak, hogy Európa részesedése 52\%-ról 68\%-ra emelkedett a vizsgált idöszak alatt.

A gépipar (elektronikával együtt) ${ }^{8}$ is a magasan nemzetköziesedett ágazatok közé sorolandó. A szektor leányvállalatainak részesedése a leányvállalatok számából $10 \%$ körül alakult, míg a vagyonból 9\%-ról 6\%-ra mérséklödött. Ennek ellenére a feldolgozóiparon belül az ágazat jelentősége erösödött. A gépiparon belül a legnagyobb súllyal az elektronika, valamint a számítástechnikai és irodai berendezéseket előállító ágazatok képviseltették magukat, a gépipari leányvállalatok közel felét ezen termékeket gyártó egységek tették ki, és a vagyonból való kétharmad arányú részesedésük is ezen ágazatok jelentőségét hangsúlyozta. Ugyancsak ezek az ágazatok voltak a leginkább nemzetköziesedettek is, és a távol-keleti államok is ezeken a területeken szereztek jelentős nemzetközi pozíciókat. A számítógépek és a félvezetök gyártása, valamint az elektronika terén a fent említett térség nemcsak az alacsony munkabérek miatt vált vonzó befektetési területté, de piacként is jelentős súlyt képvisel. Nem véletlen, hogy már a nyolcvanas évek végén több vállalat is regionális központot hozott létre a Távol-Keleten (a National Semiconductor Szingapúrban, a Motorola, a Sprague és a Zilog Hongkongban) (Dicken 1992, 374).

A kilencvenes években lezajlott területi átrendezödés következtében a legfejlettebb államok részesedése az elektronika nélküli gépipar vagyonából 70\%-ról 57\%-ra, az OECD-államok részesedése $92 \%$-ról $88 \%$-ra mérséklödött. Az elektronika terén ahol a koncentráció már jóval kisebb mértékủ volt - a legfejlettebb államok részesedése 87\%-ról 74\%-ra, az OECD-államoké 54\%-ról 42\%-ra esett vissza. A átrendezödés keretében számos elektronikai termék gyártása (háztartási gépek, audiovizuális berendezések) Ázsiában a kevésbé fejlett Kínába és más délkelet-ázsiai államba (Thaiföld, Indonézia és a Fülöp-szigetek), Európában kezdetben Írországba, majd egyre inkább a volt szocialista államokba (túlnyomórészt Magyarországra) helyeződött át, de emellett a latin-amerikai régió pozíciója is megerösödött. Ugyanakkor a K+F intenzív ágazatokban a legfejlettebb európai államok, Japán és Szingapúr egyértelmüen megörizték vezetö pozíciójukat.

A jármügyártás a leányvállalatok számát tekintve növelte feldolgozóiparon belüli részesedését, miközben a vagyonból való részesedése kissé visszaesett. Az ágazaton 
Csiki Anita : Az amerikai transznacionális vállalatok térszerveződése az 1990-es években.

Tér és Társadalom 18. évf. 2004/3. 91-110. p.

belül a leginkább globalizálódott és a legnagyobb súllyal is bíró iparág az autóipar. Az autóipari vállalatok közül a két nagy amerikai cég (a GM és a Ford Motor) már a kilencvenes évek közepén a piac egyötödét uralta, és termelésüknek fele már akkor is külföldről származott (Dicken 1992, 335). Bár a termelés nagyobb hányada még mindig a fejlett világban folyik, az elmúlt évtizedben a fejlődő világ államaiban dinamikusan nőttek az ágazat befektetései. Regionális szinten az egész amerikai kontinens - Kanadával együtt - felértékelődése figyelhetö meg, de míg az Egyesült Államok NAFTA-beli partnerei jelentős beszállítói tevékenységet végeztek (tehát az elöállított termékeket intra-firm kereskedelem formájában visszajuttatták az Egyesült Államokba), addig az önálló regionális piacként kezelt DélAmerikában a vállalatok lényegében helyi igényeket igyekeztek kielégíteni.

A nagykereskedelmi leányvállalatok részesedése a leányvállalatok számából 24\% körül mozgott, míg a vagyonból 10\%-ról 7\%-ra mérséklödött. A nagykereskedelem közel kétharmadát a tartós áruk nagykereskedelme tette ki, ezen belül kiemelkedett a professzionális felszerelések és eszközök értékesítése, mely tevékenységgel a nagykereskedelmi cégek negyede foglalkozott. A fejlett államok a legnagyobb arányban a nagykereskedelmi leányvállalatok vagyonából részesültek. Bár 1990 és 1998 között a legerösebb gazdaságok részesedése 50\%-ról 38\%-ra mérséklödött, az OECD-országok együttes részesedése ugyanezen időszak alatt csupán 4\%-kal csökkent, ami arra utal, hogy e tevékenység térszerveződésénél a piac szerepe a meghatározó. Regionális szempontból a vizsgált idöszakban nagyobb mértékben Ázsia jelentősége emelkedett, ám ez a növekedés lényegében a NIC-országok gazdasági pozíciójának erősödésével hozható összefüggésbe. A kevésbé fejlett államok közül - igaz csak kis mértékben - a latin-amerikai és a kelet-európai országok voltak képesek növelni részesedésüket. A latin-amerikai bỏvülés hátterében a karibi térség vállalatainak bővülése húzódik meg: a térségben (lényegében a Bermudaszigeteken) a kilencvenes évek végén már a teljes latin-amerikai vagyon közel fele koncentrálódott.

Már a nyolcvanas évek eleje óta gyorsan nöttek a külföldi befektetések a szolgáltatások terén is. A szolgáltatások nemzetközi áramlása és a szektorban folyó külföldi tökeberuházás a világgazdaság legdinamikusabban bővülö területe, a transznacionális vállalatok terjeszkedése is ezen a téren a legerősebb (Surányi 2000). Az UNCTAD adatai - melyek szerint a nyolcvanas évek közepe óta a folyó nemzetközi tökeáramlásnak már több mint fele ebbe a szférába irányult - is ezt a megállapitást támasztják alá. A szolgáltatások növekvő térnyerésében óriási szerepe volt egyrészt a szektort érintő liberalizációs és deregulációs intézkedéseknek, másrészt az információs forradalomnak, ami lehetővé tette az információs rendszerek kiépülését és a kommunikációs költségek csökkenését. Az ágazaton belül a nemzetköziesedés leginkább a vállalatok müködését támogató területeken fokozódott, így a külföldi pénzügyi, a technikai, az információs, az adatfeldolgozó és a tanácsadási szolgáltatások szerepe lett nemzetközi szinten is egyre jelentősebb, és a jövőben is ezeken a területeken várható további erősödés. Bár a nemzetköziesedés lényegében a legfejlettebb államok szerepét erősítette meg, de a szektor számára felértékelődtek az 
Csiki Anita : Az amerikai transznacionális vállalatok térszerveződése az 1990-es években.

Tér és Társadalom 18. évf. 2004/3. 91-110. p.

úgynevezett "off-shore" területek - amelyek túlnyomórészt "back-office" tevékenységeket végeztek - és a regionális föhadiszállásoknak helyet adó versenyképes fejlödö világbeli nagyvárosok is.

A szolgáltatásokon belül már igen jentős nemzetközi súllyal rendelkeznek a pénzügyi és biztosítási tevékenységek: e szolgáltatások együttes részesedése a leányvállalatok számából 13\%-ról 15\%-ra, a vagyonból 35\%-ról 51\%-ra nött 1990 és 1998 között. A legmagasabb területi koncentráció is a pénzügyi szférát jellemezte, és ez az évtized folyamán csak tovább fokozódott. A leányvállalatok pénzügyi vagyonából a kilencvenes évek végére a fejlett államok magasabb arányban részesedtek, mint 1990-ben: az OECD-országok részesedése 80\%-ról 85\%-ra, a legfejlettebb gazdaságok közé sorolt hat államé 60\%-ról 65\%-ra bővült. De még ezen országcsoportokon belül is igen magas a koncentráció, az OECD-s vagyon háromnegyede lokalizálódott Európában, melynek közel kétharmadát a brit vállalatok vagyona tette ki. Emellett Japán, Hollandia, Kanada és Németország szerepe volt kimagasló. Az OECD-államain kívül jelentős pozíciót szerezni csak a karibi térség (lényegében a Bahama-szigetek és az Egyesült Királyság fennhatósága alatt álló Karibi-szigetek) volt képes, ahol a leányvállalatok döntően "off-shore" pénzügyi tevékenységekre szakosodtak. Az ágazat további területi alakulását vizsgálva megállapítható az amerikai kontinens „leértékelődése” (mind Kanada, mind a karibi térség részesedése jelentősen visszaesett), Európa és Ázsia súlyának további erösödése.

A nem pénzügyi szolgáltató leányvállalatok részesedése a leányvállalatok számából 9\%-ról 12\%-ra, a vagyonból 3,5\%-ról 5\%-ra emelkedett. E leányvállalatok felét az üzleti szolgáltatásokat nyújtó egységek tették ki, melyek $50 \%$-át a számítógépes adatfeldolgozással foglalkozó egységek, 13\%-át a reklámtevékenységet végzö leányvállalatok jelentették. Emellett a menedzsmentszolgáltatások bírtak még számottevő jelentőséogel. A szolgáltatások terén a fejlett államok pozíciója - akárcsak a nagykereskedelem esetében - kiemelkedöen erös volt: az OECD tagállamai 90\%-kal részesedtek ezen vállalatok vagyonából, a legerősebb államok közé sorolt országok is a vagyon közel $60 \%$-ával rendelkeztek. Ha csak Európát vesszük alapul, megállapítható, hogy a kontinens 1998-ban mind a nagykereskedelmi leányvállalatok, mind pedig a szolgáltató egységek összesített vagyonából közel 70\%-kal részesedett. Igaz ugyan, hogy ezen a területen már nem volt mérhető olyan erös koncentráció, mint ami a pénzügyi szolgáltatások esetén volt kimutatható, de ez a tevékenység is elsődlegesen a legfejlettebb államokra koncentrálódott (csak az Egyesült Királyság és Belgium az európai szolgáltató vállalatok vagyonának felét birtokolta). Az amerikai kontinens időközben a nem pénzügyi szolgáltatások téren is veszített pozíciójából, igaz ugyan, hogy ez a visszaesés lényegében csak Kanadát érintette, Latin-Amerika egészének jelentősége további 3\%-kal erösödött. Az északi szomszédnál tapasztalt visszaesés elsösorban a kiskereskedelemben, valamint a villamosenergia, gáz-, hő- és vízellátás területén volt kimutatható. Miközben az amerikai kontinens pozíciója meggyengült, addig jelentősen fokozódott - lényegében a Japánban müködö leányvállalatok révén - Ázsia súlya. 
Csiki Anita : Az amerikai transznacionális vállalatok térszerveződése az 1990-es években. Tér és Társadalom 18. évf. 2004/3. 91-110. p.

TÉT XVIII. évf. 2004 - 3 Kitekintö 105

\section{Kelet-Európa és Magyarország az amerikai vállalatok érdekszférájában}

Az amerikai befektetők Kelet-Európában már az 1980-as évek második felében megjelentek. A hidegháborús helyzet megszủnését követően, a Szovjetunió szétesésével és a volt szocialista országokban lezajlott rendszerváltással pedig újabb beruházási lehetőségek és piacok kínálkoztak, melynek következtében fokozódott a térségbe irányuló amerikai tỏkekivitel is. Az amerikai TNC-k kezdetben nyugateurópai tevékenységüket terjesztették ki Kelet-Európára, de az Egyesült Államokból közvetlenül is érkeztek befektetők.

A legtöbb amerikai tőke a régióban Lengyelországba, Csehországba és Magyarországra érkezett (6. táblázat). A koncentráció foka a térségben igen magas, az itt létesített leányvállalatok 60\%-a még 2000-ben is e három államban lokalizálódott, s ezen államok a kelet-európai leányvállalatok vagyonának a felével rendelkeztek.

\section{TÁBLÁZAT}

A kelet-európai leányvállalatok területi megoszlása 1990 és 2000 között

(The Geographic Distribution of Affiliates in Eastern Europe between 1990 and 2000)

\begin{tabular}{lccccccccccccc}
\hline \multicolumn{10}{c}{ Részesedés a leányvállalatok számából (\%) } \\
\hline Kelet-Európa & 1990 & 1991 & 1992 & 1993 & 1994 & 1995 & 1996 & 1997 & 1998 & 1999 & 2000 \\
Csehország & 0 & 0 & 18 & 100 & 100 & 100 & 100 & 100 & 100 & 100 & 100 \\
Magyarország & 50 & 64 & 42 & 34 & 21 & 21 & 20 & 26 & 24 & 21 & 20 & 17 & 17 \\
Lengyelország & 0 & 7 & 18 & 27 & 22 & 22 & 23 & 22 & 21 & 25 & 24 \\
Oroszország & 50 & 29 & 13 & 11 & 16 & 17 & 18 & 19 & 20 & 19 & 19 \\
\hline \multicolumn{10}{c}{ Részesedés a leányvállalatok vagyonából(\%) } \\
\hline Kelet-Európa & 100 & 100 & 100 & 100 & 100 & 100 & 100 & 100 & 100 & 100 & 100 \\
Csehország & 0 & 0 & 37 & 13 & 16 & 16 & 15 & 12 & 11 & 11 & 11 \\
Magyarország & 0 & 92 & 44 & 38 & 31 & 27 & 20 & 17 & 17 & 14 & 13 \\
Lengyelország & 0 & 0 & 12 & 18 & 18 & 20 & 20 & 21 & 18 & 23 & 23 \\
Oroszország & 0 & 0 & 5 & 7 & 11 & 13 & 15 & 17 & 14 & 13 & 12 \\
\hline
\end{tabular}

Forrás: Bureau of Economic Analisys (BEA) alapján saját számítás.

A kilencvenes évek elején még egyértelmüen Magyarország számított a régió elsőszámú befektetési terïletének (a piacgazdaság kiépülése és a privatizáció terén élen járt az ország), az évtized végére azonban részesedésünk jelentősen mérséklődött - addigra ugyanis megszüntek azok az előnyök, amelyek korábbi versenyképességünket biztosítani tudták. Ezzel párhuzamosan elöször Lengyelország, majd Csehország szerepe értékelődött fel számottevỏen. 1997-ben már Lengyelországban múkỏdött a legtöbb amerikai vállalat, és 1999-ben és 2000-ben már a cseh részesedés is meghaladta a magyarországit. A vagyonból való részesedést tekintve részben 
Csiki Anita : Az amerikai transznacionális vállalatok térszerveződése az 1990-es években.

Tér és Társadalom 18. évf. 2004/3. 91-110. p.

106 Kitekintö

TÉT XVIII. évf. 2004 a 3

hasonló tendencia rajzolódik ki. 1991 és 2000 között Magyarország részesedése 91\%-ról 13\%-ra csökkent, miközben Lengyelország részesedése lett egyre jelentösebb. 1997-ben már e mutató szerint is Lengyelország vette át a vezető szerepet. De a leányvállalatok számából való részesedéssel ellentétben a vagyonból való részesedést tekintve Magyarország mindvégig megörizte Csehországgal szembeni elönyét.

Kelet-Európának az amerikai vállalati vagyonból való részesedése ágazatonként igen eltéröen alakult, és ennek a vagyonnak a területi megoszlása is változatosságot mutat (7. táblázat).

\section{TÁBLÁZAT}

Amerikai vállalatok Kelet-Európában, 2000

(U.S. Corporations in Eastern Europe, 2000)

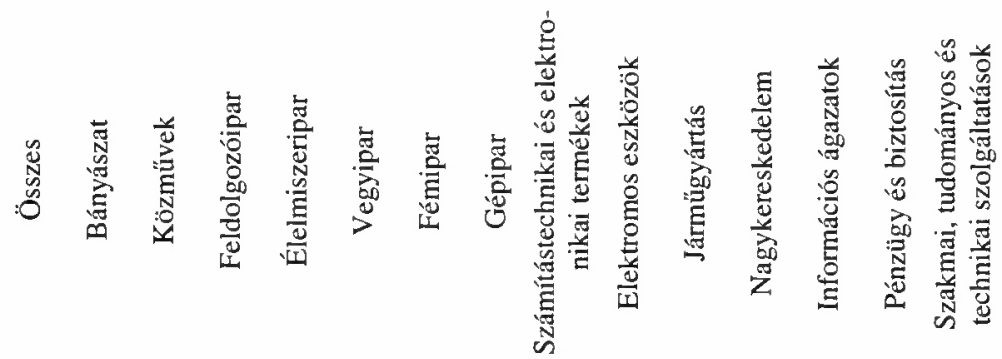

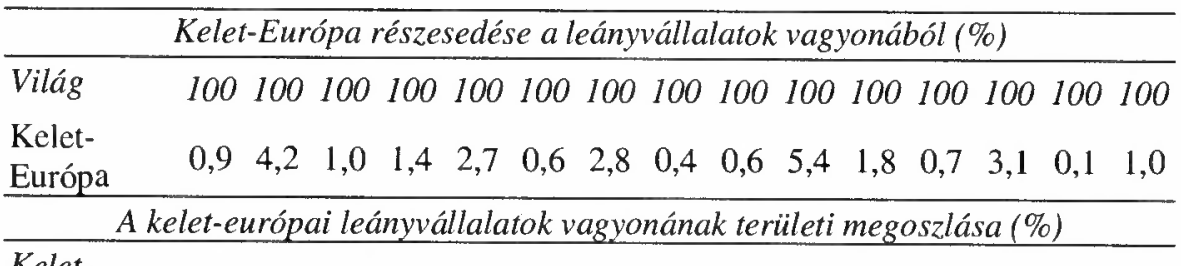

Kelet-

Európa

100100100100100100100100100100100100100100100

$\begin{array}{llllllllllllllll}\text { Csehország } & 11 & 0 & 0 & 15 & 4 & 29 & 4 & 25 & 19 & 2 & 24 & 17 & 9 & 22 & 16\end{array}$

$\begin{array}{llllllllllllllll}\text { Magyaro. } & 13 & 0 & \text { na } & 26 & 7 & 17 & 23 & 8 & 80 * & 74 & 24 & 24 & 14 & 6 & 11\end{array}$

$\begin{array}{llllllllllllllll}\text { Lengyelo. } & 23 & 0 & 1 & 32 & 50 & 29 & 9 & 10 & 2 & 5 & 46 & 25 & 65 & 41 & 16\end{array}$

$\begin{array}{llllllllllllllll}\text { Oroszo. } & 12 & 12 & 0 & 11 & 21 & 20 & 0 & 0 & 2 & 1 & 2 & 21 & 8 & 25 & 8\end{array}$

A magyarországi leányvállalatok vagyonának ágazati megoszlása (\%)

Magyar-

ország

$\begin{array}{lllllllllllllll}100 & 0 & \text { na } & 68, & 2 & 4 & 7 & 0,4 & 13 * & 19 & 12 & 11 & 9 & 3 & 2\end{array}$

*1999-ben!

Forrás: Bureau of Economic Analisys (BEA) alapján saját számítás.

Térségünk még nem került be az amerikai nagykereskedelmi és pénzügyi vállalatok érdekszférájába. Az információs ágazatok nagyobb súlyt képviseltek, bár e befektetések túlnyomó része is csak Lengyelországra koncentrálódott. A térség az összes amerikai bányászati vagyonból már nemzetközi szinten is magas arányban részesedett, de ezek a befektetések lényegében csak a szovjet utódállamokban 
Csiki Anita : Az amerikai transznacionális vállalatok térszerveződése az 1990-es években.

Tér és Társadalom 18. évf. 2004/3. 91-110. p.

eszközölt befektetéseket jelentették. 2000-ben Kelet-Európa a külföldön lévö amerikai feldolgozóipari vagyon 1,4\%-át tudhatta magáénak. Az ágazaton belül az elektronika szerepe volt világszinten is kiemelkedö, e területen a befektetések háromnegyede Magyarországon realizálódott. A fémipar, a jármügyártás és az élelmiszeripar is a nagyobb súlyt képviselö ágazatok között tarthatók számon. A fémiparban a szovjet utódállamokban és a Magyarországon eszközölt befektetések domináltak, az élelmiszeripar terén Lengyelország vezető szerepe volt vitathatatlan, míg a jármügyártó leányvállalatok vagyonának közel fele müködött Lengyelországban, további 24-24\%-kal Csehország és Magyarország részesedett a vizsgált évben.

\section{Az amerikai vállalatok magyarországi befektetéseinek ágazati megoszlása}

A hazánkban befektetett amerikai tőke megoszlása nagyfokú ágazati koncentrációt mutat (7. táblázat). A primer szektor és a közmühálózat iránt az érdeklődés mindvégig minimális volt. 2000-ben az amerikai érdekeltségü leányvállalatok vagyonának több mint kétharmada koncentrálódott a feldolgozóiparban, ezen belül az amerikai vállalatok a legnagyobb súllyal az elektronikában voltak képviselve. Sajnos az ágazat problémái már a magyar gazdaságot is elérték, melynek jeleként látványos kivonulásokról és leépítésekról szóltak a médiahírek. A válság nem kerülte el a hazánkban termelő amerikai vállalatokat sem, így érintette az IBM-et és a Flextronics-ot is. A hazai feldolgozó-ipari vagyon további $18 \%$-át a jármüipar vagyona tette ki. Bár nemzetközi szinten ez az iparág is küszködik nehézségekkel, a magyarországi gépjármügyártás változatlanul húzóágazatnak számít. A hazai autógyártó cégeket elsősorban az Opel-GM és a Ford (Visteon Hungary Kft.) képviseli, mindkét cég már 1990-ben megkezdte magyarországi tevékenységét. Mellettük a jármügyártás piacán említésre érdemes még a budapesti székhelyủ NABI North American Bus Industries Rt., e vállalat autóbuszgyártással foglalkozik. Az amerikaiaknak jelentős érdekeltségeik vannak a magyarországi fémiparban is, ez lényegében annak a székesfehérvári Alcoa befektetésének köszönhetö, amely alumínium félkész termékeket állít elő. Az amerikai leányvállalatok hazánkban befektetett vagyonának további ágazati megoszlása a következőképpen alakult: a nagykereskedelem 10,5\%-os, az információs ágazatok 9\%-os, a pénzügy 3\%-os, a szolgáltatások $2 \%$-os részesedéssel bírtak.

\section{Összegzés}

A 20. század utolsó évtizedében tovább folytatódott az amerikai cégek nemzetköziesedése. Ám, hogy e vállalatok befektetéseiket hol valósították meg, azt az egyes országok versenyképessége nagyban meghatározta. Mivel az államok mérete, fejlettségük színvonala és erőforrással való ellátottságuk igen eltérő, így másként profitálnak a fokozódó globalizációból is. Maguk a vállalatok is másként ítélik meg a képzett munkaerővel, fejlett és teljes körü infrastrukturális háttérrel, 
Csiki Anita : Az amerikai transznacionális vállalatok térszerveződése az 1990-es években.

Tér és Társadalom 18. évf. 2004/3. 91-110. p.

fizetóképes kereslettel bíró államok körét, megint más kategóriába sorolják azokat az újonnan iparosodó és átalakuló gazdaságokat, amelyek alacsonyabb munkabérü, de még mindig eléggé képzett munkaerövel rendelkeznek, és megint más megítélés alá esnek azok a fejlődó államok, amelyek infrastrukturális helyzetük, munkaerejük szakképzettsége, népességük vásárlóereje tekintetében egyre inkább eltávolodnak az elöző két csoport tagjaitól.

Bár az amerikai vállalatok térszerveződésének egyik jellemzője volt a dekoncentráció, a külföldi leányvállalatok földrajzi megoszlását még mindig magas fokú területi koncentráció jellemzi. 2000-ben a többségi amerikai tulajdonban lévő leányvállalatoknak $60 \%$-a múködött a világ fejlett államaiban, a legfejlettebb államokban lokalizálódott a leányvállalatok 40\%-a. S, ha a leányvállalatok vagyon szerinti földrajzi megoszlását vesszük alapul, még inkább a fejlett államok dominanciája rajzolódik ki. Ezzel együtt az amerikai vállalatok térszerveződésében mégis kimutatható volt egyfajta dekoncentrációs folyamat. A 20. század végének eseményei (a kínai reform, a volt szocialista országok rendszerváltása, deregulációs és liberalizációs intézkedések, technológiai fejlődés stb.) természetesen a vállalatok térbeli szerveződésére is hatással voltak. A hidegháborús helyzet megszünésével Kelet-Európa mint új beruházási lehetőség és piac jelent meg a nemzetközi gazdasági térben. Bizonyos területeken Latin-Amerika pozíciója is erősödött, és tovább fokozódott az ázsiai feltörekvő piacok jelentősége is. Az utóbbi térségben Japán és az újonnan iparosodott délkelet-ázsiai államok mellett az alacsonyabb jövedelmü délkelet-ázsiai országok, valamint Kína és India is egyre intenzívebben kapcsolódott be a nemzetközi termelési folyamatba. Ugyanakkor a fejlődő világ nem értékelödött fel egységesen, ennek megfelelően az oda irányuló tőkekivitelt is magas fokú koncentráció jellemzi. A közepesen fejlett államok viszonylag megfelelö infrastrukturális rendszerekkel, gazdasági és politikai stabilitással, valamint olcsó munkaeröforrással rendelkezve a fejlett világban már elavultnak számító technológiával még mindig versenyképesen tudnak termelni, de a fejlődő világ nagyobb fele a tőke hiánya révén a globalizáció folyamatába nem volt képes hatékonyan bekapcsolódni.

Bár a közel-keleti térség szerepe sem jelentős, ám ez sokkal inkább kulturális és politikai, mint sem gazdasági okokkal hozható összefüggésbe, és az iszlám világ esetében a kulturális eltérés és a növekvő amerikaellenesség miatt a jövöben sem várható jelentősebb változás.

Ágazati szempontból a kitermelö- és a feldolgozó-ipari ágazatok pozícióvesztésének és a szolgáltatási szféra felértékelődésének lehettünk a tanúi. Ennek eredményeképpen a kilencvenes évek végén a feldolgozóipar 35\%-kal, a kitermelőipar $4 \%$-kal, a nagykereskedelem 23\%-kal, a szolgáltatási és egyéb szféra $37 \%$-kal részesedett a leányvállalatok számából. Még inkább kirajzolódik az egyes ágazatok szerepe a vagyon szerinti megoszlást alapul véve. A külföldi leányvállalatok vagyonának ágazati megoszlását tekintve a kilencvenes évek végén a feldolgozóipar $23 \%$-kal, a kitermelöipar 4\%-kal, a nagykereskedelem $8 \%$-kal, a szolgáltatási és egyéb szféra pedig már $65 \%$-kal részesedett a leányvállalatok vagyonából. 
Csiki Anita : Az amerikai transznacionális vállalatok térszerveződése az 1990-es években. Tér és Társadalom 18. évf. 2004/3. 91-110. p.

$\mathrm{Az}$ olajipari vállalatok külföldi beruházásokból való részesedése számottevően csökkent. A területi átrendeződés keretében pedig a fejlett államok szerepének további mérséklődése volt kimutatható, amivel párhuzamosan az olajcégek érdekeltségeiket Latin-Amerikában, Afrikában, Ázsiában és a szovjet utódállamokban növelték.

A fejlett világban a szolgáltatások szerepének felértékelödésével együtt járt a feldolgozóipar részesedéscsökkenése is. A fejlett államok vállalatai azonban e tevékenységeiket nem szüntették meg, csak egyes fázisait áttelepítették a fejlődő világba. Így - miközben a világ fejlett államai a magasabb technológiai szintü ágazatokban továbbra is megőrizték vezetó pozícióikat - a feldolgozóipar egyéb terén az alacsony és közepes jövedelmü latin-amerikai és ázsiai államok jelentősége értékelődött fel.

Bár a nyolcvanas évek eleje óta gyorsan nő a külföldi tőke a nagykereskedelmi, a pénzügyi és az egyéb szolgáltatások terén, a növekvő nemzetköziesedés ellenére ezen tevékenységek elsődleges célterületei továbbra is a fejlett államok maradtak, ugyanakkor a szektor számára már felértékelödtek az úgynevezett "off-shore" területek és a vállalatok regionális bázisainak helyet adó fejlődő világbeli nagyvárosok is. Igaz ugyan, hogy a szolgáltatási szférán belül eddig elsősorban a vállalatok müködését támogató szolgáltatások területe volt jelentős, a jövőben ezen területek további erősödése mellett a lakossági szolgáltatások növekvő globalizációja is várható.

E tanulmány az amerikai vállalatok térszervezödésének felvázolására tett kísérletet, de nem tért ki részletesen arra, hogy az egyes államok adottságai és képességei miként befolyásolják a nagyvállalatok lokalizációs döntéseit. Az egyes államok más-más erőforrásokkal rendelkeznek, eltérö termelékenységgel és hatékonysággal termelnek, különbözö munkabérekkel dolgoznak stb., a vállalatok pedig ezeket a tényezöket mérlegelve döntenek befektetéseikröl. Ezért a továbbiakban érdemes megvizsgálni, hogy iparágak és vállalati funkciók szerint melyek a legfontosabb lokalizációs tényezők, mely államok képesek ezeknek leginkább megfelelni, esetleg egyedi feltételeket kínálva akár kitüntetett helyzetbe is kerülni, ezáltal regionális központtá is válni.

\section{Jegyzetek}

1 www.bea.doc.gov

2 A vagyon szerinti legnagyobb vállalatok listája.

${ }^{3}$ TNI = ([külföldi vagyon / teljes vagyon + küilföldi értékesítés / teljes értékesítés + külföldi foglalkoztatottak száma / teljes foglalkoztatottak száma] $/ 3)^{*} 100$

4 A BEA besorolása szerint Kelet-Európa államai a következők: Albánia, Azerbajdzsán, Bulgária, Csehország, Észtország, Fehéroroszország, Grúzia, Kazahsztán, Lengyelország, Lettország, Litvánia, Magyarország, Moldávia, Oroszország, Örményország, Románia, Szlovákia, Tádzsikisztán, Türkmenisztán, Ukrajna, Üzbegisztán.

Az Egyesült Államok ,partnerei” a legfejlettebb államok - a vizsgált időszakban még G7-ek - csoportjában (Egyesuilt Királyság, Franciaország, Japán, Kanada, Németország, Olaszország).

6 A BEA regionális besorolása szerint Ausztrália és Óceánia Ázsiához tartozik.

7 Az első hullámba sorolt „NIC-országok”: Dél-Korea, Hongkong, Szingapúr, Tajvan.

8 A BEA statisztikája 1998-ig az elektromos és elektronikai termékek gyártását a gépipar egyéb területeitől elkülönítve tartotta nyilván. 
Csiki Anita : Az amerikai transznacionális vállalatok térszerveződése az 1990-es években.

Tér és Társadalom 18. évf. 2004/3. 91-110. p.

110 Kitekintö

TÉT XVIII. évf. 2004

\section{Irodalom}

Dicken, P. (1992) Global shift. The internationalization of Economic Activity. Paul Chapman Publishing Lid., London.

Global 500, 2000. (2001) - Fortune. July 23.

Simai M. (2000) A müködötöke kivitele és a technikai fejlödés a 21. század küszöbén. Oktatási Minisztérium, Budapest.

Surányi S. (2000) A szolgáltatások internacionalizálódása a globális gazdaságban. - Blahó A. (szerk.) Nemzetgazdaság - Regionalitás - Világgazdaság. Tanulmányok Simai Mihály Akadémikus 70. születésnapja tiszteletére. Aula, Budapest. 151-162. o.

World Investment Report (1996-2000) (2002) UN.UNCTAD. New York - Geneva. 